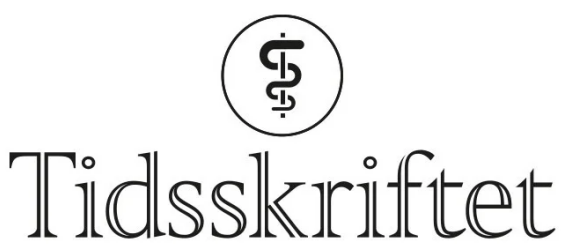

DEN NORSKE LEGEFORENING

\title{
Vi trenger en hippokratisk ed for de ufødte
}

KRONIKK

\section{DAG O. HESSEN}

d.o.hessen@mn.uio.no

Dag O. Hessen er professor i biovitenskap ved Universitetet i Oslo og leder av Centre for

Biogeochemistry in the Anthropocene (CBA).

Forfatteren har fylt ut ICMJE-skjemaet og oppgir ingen interessekonflikter.

\section{Klimaendringene er samtidens største helseutfordring. De vil utgjøre en økende direkte og indirekte trussel mot kommende generasjoner.}

En tegneseriestripe fra våren 2020 fanger noe viktig ved situasjonen vi står i: To menn i hvit frakk står og betrakter de velkjente koronakurvene. Den ene bemerker til den andre at «jeg skal være glad når dette er over». Det ingen av dem ser, er de langt mer dramatiske klimakurvene som reiser seg som flodbølger bak ryggene deres. The Lancet countdown on health and climate change hevder at «klimaendringer er den største globale helsetrusselen i det 21. århundret, men også den største muligheten til å omdefinere de sosiale og miljømessige faktorene for helse» $(\underline{1}, \underline{2})$. Her hjemme ble dette hevdet i en artikkel i Tidsskriftet allerede for ti år siden (3). De påfølgende årene har styrket påstanden.

Den ferske, sjette rapporten fra The Intergovernmental Panel on Climate Change (IPCC) fastslår at verden nå er varmere enn den har vært på 125000 år, og dagens $\mathrm{CO}_{2^{-}}$ konsentrasjoner er høyere enn de har vært de siste to millioner år (4).). Dagens kurs peker mot 3 graders temperaturøkning innen år 210o. Det er ingen gitt å vite hva slags ekstremer som da venter, heller ikke ved 2 grader, som tilhører de mer optimistiske estimatene. Med dagens kurs vil 1,5 graders økning passeres om et par tiår. Selv de mest konservative scenariene anser 2 graders temperaturøkning som ganske sannsynlig i år 2050 - med dagens utslipp. Rapporten peker som forventet også på ikke bare økt sannsynlighet for mer av ekstremhendelsene vi allerede ser, men at det ekstreme vil bli vanligere: 10ooårsflommen vil komme hvert 100 år, og det vil skje flere steder.

Fram til nå har økosystemene gjort oss en formidabel tjeneste ved sin netto binding av $\mathrm{CO}_{2}$. Faktisk tas over halvparten av våre utslipp opp på denne måten. Skulle økosystemenes evne til å ta opp $\mathrm{CO}_{2}$ svekkes eller i verste fall reverseres, har vi virkelig problemer. Noe av det mest skremmende i IPCC-rapporten er risikoen for at land og hav kan endres fra å bedrive et netto opptak av $\mathrm{CO}_{2}$ til å ha et netto utslipp til atmosfæren. Dette ser vi allerede 
konturene av gjennom redusert evne til $\mathrm{CO}_{2}$-opptak i tropiske skoger, økt tining av permafrost som avgir $\mathrm{CO}_{2}$ (i verste fall også metan $\left(\mathrm{CH}_{4}\right)$ ), skogbranner og et varmere og surere hav. Slike selvforsterkende tilbakekoblinger kan føre til klimatiske vippepunkter. Det dreier seg altså ikke «bare» om $\mathrm{CO}_{2}$ og klima, men også om tap av natur og dermed svekkelse av økosystemtjenester som $\mathrm{CO}_{2}$-opptak, karbonlagring og flomdemping.

\section{Klima som hovedtrussel}

Ingenting er så potensielt truende for folkehelse som klimaendringer. Direkte krever de allerede betydelige ofre i flommer, brann og ekstreme hetebølger, men dette er ifølge IPCCrapporten bare forløperen for hva vi har i vente. Og de indirekte effektene vil bli større fordi nettopp sykdommer, vann- og matmangel, dårligere sanitærforhold og migrasjoner som følge av slike reduserte livsbetingelser, ekstremhete, branner og stigende havnivå i seg selv utgjør store sosiale og helsemessige utfordringer. Klimaflyktninger er allerede et etablert begrep, og det vil kunne ramme ulike regioner av ulike årsaker.

«Ingenting er så potensielt truende for folkehelse som klimaendringer.

Direkte krever de allerede betydelige ofre i flommer, brann og ekstreme hetebølger»

EU-kommisjonen beskriver dette i klartekst i sin rapport Oppdrag: et klimarobust Europa (5): «Covid-19-pandemien har lært oss en lekse om hvor tett naturmiljø, samfunn og helse er integrert. Hva vi har opplevd hittil, er imidlertid en mild forsmak på sjokkene som venter oss som følge av klimaendringer». En slik helhetlig tilnærming er også poengtert i EATLancet-rapporten, som på utmerket vis demonstrerte de tette sammenhengene mellom helse og matproduksjon, ernæring, arealbruk og klima (므).

Tilsvarende skriver Miljødirektoratet i sitt notat Klimaendringer og helse at «Norges befolkning har generelt god helse, og helsemessig står vi relativt godt rustet mot virkninger av klimaendringer. Likevel vil mer nedbør, hetebølger og tørkeperioder få betydning for helsen vår» (.7.). Rapporten setter helseeffekter (død, skade, blokkering av utrykningskjøretøy) som et resultat av flom og skred på topp, fulgt av varmebølger, nye sykdommer, redusert mattilgang, mer allergi og dårligere luftkvalitet, frigivelse av toksiner fra jord og deponier samt økt behov for sprøytemidler.

\section{Den levelige nisjen}

Bortsett fra de akutte konsekvensene av klimakatastrofer (flom, ras, brann) er akutt varmedød et problem som framstår som stadig mer relevant også i områder som tidligere har vært ukjent med dette, jamfør ekstremtemperaturene opp mot $50{ }^{\circ} \mathrm{C}$ som ble registrert i Canada på forsommeren og senere på USAs vestkyst, og sensommerens temperaturrekorder i Europa. Vi har allerede hatt varmebølger med flere titalls tusen dødsfall ( $\underline{8})$, og en «våtkuletemperatur» som overstiger $35^{\circ} \mathrm{C}$, forventes å inntre hyppigere og på flere steder. Dette vil forårsake omfattende akutt varmedød.

\section{«Det er anslått at 1-3 milliarder mennesker kan havne på utsiden av den} beboelige nisjen i løpet av 50 år»

Våtkuletemperaturen beregnes på grunnlag av lufttemperatur og relativ luftfuktighet. Økt luftfuktighet øker risikoen for at høye temperaturer gir akutt varmedød, fordi kroppen ikke makter å kvitte seg med overskuddsvarme. Dette er bare én av mange faktorer som går 
inn i beregninger av hvilke områder av planeten som vil bli ubeboelige under ulike klimascenarier (9.). Selv om menneskeheten bebor de fleste av planetens klimatiske ekstremområder, så er den menneskelige klimanisjen relativt smal i den varme enden, både når det gjelder mattilgang, vann og temperaturtoleranse. Det er anslått at 13 milliarder mennesker kan havne på utsiden av den beboelige nisjen i løpet av 50 år (9.). Satt på spissen står valget mellom forflytning, om man kan, eller høy risiko for varmedød. Det er også verdt å minne om at varme, tørke, brann og flom innebærer enorme tap også for klodens øvrige livsformer.

\section{Klima og korona}

Allerede den 5. mars 2020 spurte The Guardians kommentator Owen Jones: «Hvorfor behandler vi ikke klimakrisen med samme alvor som korona?» Som han påpekte, har ikke klimakrisen bare de samme alvorlige virkningene på helse og økonomi som virusepidemien, klimakrisen er faktisk langt mer alvorlig allerede. Den vil også fortsette å utvikle seg over tid, mens koronapandemien før eller siden vil gå mot en slutt.

Owen var naturligvis ikke alene om å stille seg spørsmålet. Forklaringen er imidlertid åpenbar: Covid-19 er en konkret trussel her og nå. Gjennom den ikoniske framstillingen av en kule med røde tentakler ble den enda mer konkret ved at det usynlige viruset ble gjort synlig for oss. Covid-19 rammet (og rammer) umiddelbart, og sykdommen går også utover mennesker vi kjenner. Ja, du og jeg kan bli syke. Viruskrisen hadde (og har) dessuten en direkte effekt på våre liv gjennom nedstenging av samfunnet, tapte arbeidsplasser, reisebegrensninger, håndvask og munnbind samt generelle innskrenkninger i vår frihet. I mange uker var nyhetene preget av alvorlige politikere og helsetopper som med bekymringsrynker daglig understreket alvoret i situasjonen. Det gjorde at vi i «en kollektiv dugnad" godtok de formidable begrensningene vi ble pålagt. Ja, selv hytta i påskeferien måtte unnværes. Her ble også faglige råd fulgt, noe klimapolitikken kunne dra lærdom av.

Det er ikke merkelig at det er slik. Vi er evolusjonært innrettet mot å håndtere umiddelbare og konkrete trusler. Både som individer og fellesskap er vi gode til det, mens vi er tilsvarende dårlig på materielle forsakelser til beste for framtiden og de ennå ufødte. Vi trenger en politikk, også på helseområdet, som har lange tidsperspektiv og som tar høyde for langsiktige klimarisikoer.

\section{Naturtap fører til zoonoser og pandemier}

Som nevnt henger naturtap og klima tett sammen, og naturinngrep innebærer også økt risiko for pandemier. En omfattende analyse av $6800 \emptyset$ kosystemer på seks kontinenter viser mekanismene bak koblingen mellom naturødeleggelse og pandemier (므). Både ebola, aids og rabies og en akronymrik gruppe av sykdommer som mers, sars, influensa $\mathrm{A}$ ( $\mathrm{H}_{1} \mathrm{~N}_{1}$ ) og nipahvirusinfeksjon kan spores tilbake til tett kontakt mellom mennesker og dyr. Likevel måtte det en koronapandemi til før problemet ble tatt på alvor.

Det har også vært en markant økning i antall zoonoser de senere årene. Mye av årsaken til dette er at vi og våre husdyr trenger inn i nye områder, at vi hugger ned eksisterende skog og fragmenterer økosystemer, noe som fører til at vi oftere kommer i tett kontakt med ville dyr. Dette fremmer spredning av virus, bakterier og andre patogener til mennesker, enten direkte eller via husdyr.

«Vi trenger framtidshåp, men på bakgrunn av handling. Tidsvinduet krymper, mens konsekvensene for framtiden øker» 
En annen årsak til økningen er at redusert biologisk mangfold synes å fremme noen få arter med spesielt stort potensial for smittespredning, som rotter, flaggermus og enkelte primater. Særlig flaggermusbestander er reservoarer for virus som forårsaker ebola, nipahvirusinfeksjon, sars - og nå altså covid-19 - hos mennesker. Når deres naturlige leveområder ødelegges, tvinges de til å hente næring der mennesker og husdyr oppholder seg. Og da øker smitterisikoen. Folketall og forbruk er felles drivkrefter for klimaendringer og naturtap. Disse problemene krever en systemtilnærming. Utfordringene må også tas tak i gjennom utdanningen (11).

\section{Tap av fremtidshåp}

De helsemessige konsekvensene av klimaendringer dreier seg ikke bare om direkte og indirekte effekter av klimaendringer i seg selv, men også om psykologiske effekter, som angst (12). Greta Thunberg-generasjonen spør seg om det finnes en framtid når utsiktene synes så mørke. Dette reiser spørsmålet om hvordan risiko bør kommuniseres. Det finnes ingen enkel oppskrift på dette, bortsett fra å holde seg til det forskningen viser, summert gjennom IPCCs rapporter. Situasjonen er alvorlig. Verden vil likevel bestå, menneskeheten også, men etter alt å dømme til økende kostnader for fysisk og psykisk helse. Vi trenger framtidshåp, men på bakgrunn av handling. Tidsvinduet krymper, mens konsekvensene for framtiden øker. Vi trenger en politikk med et tusenårsperspektiv - og en hippokratisk ed for de ufødte.

\section{LITTERATUR}

1. Costello A, Abbas M, Allen A et al. Managing the health effects of climate change. Lancet 2009; 373: 1693-733. [PubMed][CrossRef]

2. Watts N, Amann M, Arnell N et al. The 2020 report of The Lancet Countdown on health and climate change: responding to converging crisis. Lancet 2021;397: 1693-733.

3. Kvåle G, Fadnes LT, Tryland M et al. Klimaendringer - vår tids største helsetrussel. Tidsskr Nor Legeforen 2011;131:1670-2. [PubMed][CrossRef]

4. Sixth Assessment Report - IPCC. AR6 Climate Change 2021: The Physical Science Basis. https://www.ipcc.ch/report/ar6/wg1/ Lest 17.8.2021.

5. Hedegaard C, Mysiak J, Lera St. Clair A et al. Proposed Mission: A Climate Resilient Europe: Prepare Europe for climate disruptions and accelerate the transformation to a climate resilient and just Europe by 2030. Brussels: European Commision, 2020. https://ec.europa.eu/info/publications/climateresilient-europe_en Lest 17.8.2021.

6. Willett W, Rockström J, Loken B et al. Food in the Anthropocene: the EAT-Lancet Commission on healthy diets from sustainable food systems. Lancet 2019; 393: 447-92. [PubMed][CrossRef]

7. Miljødirektoratet. Klimaendringer og helse.

https://www.miljodirektoratet.no/ansvarsomrader/klima/for-

myndigheter/klimatilpasning/klimatilpasning-i-sektorer/helse/ Lest 17.8.2021.

8. Calleja-Agius J, England K, Calleja N. The effect of global warming on mortality. Early Hum Dev 2021; 155: 105222. [PubMed][CrossRef]

9. Xu C, Kohler TA, Lenton TM et al. Future of the human climate niche. Proc Natl Acad Sci U S A 2020; 117: 11350-5. [PubMed][CrossRef]

10. Gibb R, Redding DW, Chin KQ et al. Zoonotic host diversity increases in human-dominated ecosystems. Nature 2020; 584:398-402. [PubMed][CrossRef]

11. Goshua A, Gomez J, Erny B et al. Addressing climate change and its effects on human heath: A call to action for medical schools. Acad Med 2021; 96:324-8. [PubMed][CrossRef]

12. Smith M. International poll: most expect to feel impact of climate change, many think it will make us extinct. https://yougov.co.uk/topics/science/articles-reports/2019/o9/15/international-pollmost-expect-feel-impact-climate Lest 17.8.2021. 
Publisert: 6. september 2021. Tidsskr Nor Legeforen. DOI: 10.4045/tidsskr.21.0593

Mottatt 17.8.2021, første revisjon innsendt 17.8.2021, godkjent 17.8.2021.

(C) Tidsskrift for Den norske legeforening 2023. Lastet ned fra tidsskriftet.no 26. april 2023. 